\title{
Variation in morphometric characters, germination and oil content of Terminalia bellirica (Gaertn.) Roxb. seeds collected from various provenances of Odisha, India
}

\section{Harekrishna Das*}

Department of NRM, College of Forestry, Odisha University of Agriculture and Technology, Bhuvaneshwar (Odisha), India

\section{Saswat Nayak}

Department of FPU, College of Forestry, Odisha University of Agriculture and Technology, Bhuvaneshwar (Odisha), India

Diptimayee Sadangi

Department of FPU, College of Forestry, Odisha University of Agriculture and Technology, Bhuvaneshwar (Odisha), India

${ }^{*}$ Corresponding author. E. mail: harekrishnadas009@gmail.com

\section{Article Info}

https://doi.org/10.31018/ jans.v12i3.2310 Received: June 30, 2020 Revised: July 26, 2020 Accepted: August 7, 2020

\section{How to Cite}

Das, H. et al. (2020). Variation in morphometric characters, germination and oil content of Terminalia bellirica (Gaertn.) Roxb. seeds collected from various provenances of Odisha, India. Journal of Applied and Natural Science, 12(3): 319 - 327. https:// doi.org/10.31018/jans.v12i3.2310

\begin{abstract}
The wide distribution of Terminalia bellirica in natural forests of Odisha has a good opportunity to identify better genotypes with higher oil yielding potential. The study related to variation in oil content, morphometric characters and germination of Terminalia bellirica (Gaertn.) Roxb. seeds was carried out in nine provenances viz. Deogan, Bolangir Kasturi Bahal, Narada, Kantamal, Jeypore, Gunupur, Kuchinda and Ghatikia of Odisha (India) keeping in the importance of the seed oil for biodiesel production, soap industry and medicinal values. T. bellirica is widely distributed in Odisha with gregarious fruiting of which most of the fruits remain unused except used as myrobalan for medicinal purposes. It revealed that Kantamal provenance expressed highest fruits length $(3.87 \mathrm{~cm})$ and 100 fruit weight $(1340.17 \mathrm{gm}), 100$ seed weight $(649.05 \mathrm{gm})$ and 100 kernel weight(99.43gm) with maximum oil yield which can be taken up for further improvement study. However, the progeny testing at nursey level was also found to have the same provenance performing best for germination and seedling characters.
\end{abstract}

Keywords: Morphometric, Germination, Oil content, Provenances, Seeds, Terinalia bellirica

\section{INTRODUCTION}

Among the bio-energy, plant route is considered very promising because of its renewable nature and sustained production with low cost maintained. Bio-diesel produced from plants yielding oil is fast emerging as a viable alternative to petrol diesel, particularly in the face of its diminishing supply and the resulting steep increase in price (Demirbas et al., 2016). Because of the heavy requirement of edible oil, non-edible oil yielding plants are considered ideal for Indian condition for the production of biodiesel (Chhetri et al., 2008). India has many tree-borne oilseeds of which Terminalia bellirica (Gaertn.)Roxb. has a lot of potentials (Sarin et al., 2010; Marwaha et al., 2019; Rudreshaiah, 2020). T. bellirica is commonly known as beleric myrobalan and locally called 'Bahada' belonging to family Combretaceae. It is a deciduous tree of about height 20-30 m and 2-3 m in girth distributed throughout the Indian dry and moist deciduous forests, Srilanka, and South East Asia up to an elevation of 1200 meters in a wide range of ecologies. The fruits are ovoid grey drupes and seeds are used as aphrodisiac and oil extract from the seed pulp is used in the treatment of rheumatism (Deb et al., 2016), leucoderma and alopecia. Modern investigations have also proved the laxative activity of the oil (Chatterjee, 2000; Ahn, 2002).

The oil extracted from the seed of $T$. bellirica was also found to be a potential source for biodiesel extraction (Sarin, 2010) and also in soap industries. Odisha lies in the tropical zone between latitudes of $17^{\circ} 47^{\prime} \mathrm{N}$ to 
$22^{\circ} 34^{\prime} \mathrm{N}$ and longitudes $82^{\circ} 22^{\prime} \mathrm{E}$ to $87^{\circ} 29^{\prime} \mathrm{E}$. It has a recorded forest area of $58,136 \mathrm{~km} 2$ which is $37.34 \%$ of the total geographical area of the state. Odisha has 18 forest types belonging to 4 forest type groups, i.e. Tropical semi-evergreen, Tropical dry deciduous, Tropical moist deciduous and Littoral and swamp forest. It is well established that many tree species with a wide range of geographical diversity exhibit physiological, morphological, biochemical and genetic variations as an adaptation to varying environmental condition (Prativa,2013). T. bellirica trees growing in various provenances also show variation in seeds, seedling traits and oil content (Salami, and Akinyele, 2015; Gupta et al., 2016; Sharma et al.,2016;). It is an important NTFP of Odisha and widely distributed throughout the state. Considering the importance of the variability in seed characters and oil content of $T$. bellirica seeds from different provenances of Odisha, the present study was carried out to find out the variation in seed morphometric characters, oil content, germination and seedling traits of this tree.

\section{MATERIALS AND METHODS}

Selection of sample trees was made in each of the provenances of $T$. bellirica (Gaertn.) Roxb. where healthy trees of the nearly same diameter at breast height $(40-50 \mathrm{~cm})$ were considered and other morphometric characters like tree height, crown area, 100 fruit weight and fruit length were also taken into consideration. Five sample trees were collected from each provenance. Basing on the higher values of morphometric characters like 100 fruit weight and fruit length ( Kaushik et al., 2007 ) 15 Candidate Plus Trees
(CPTs) were identified from each provenance and the details of the provenances of the state Odisha of India are given in Table 1.

Three samples of fruits with 100 fresh and fully ripened matured fruits per sample were collected from each CPT. The fruit length $(\mathrm{cm})$ and fruit width $(\mathrm{cm})$ were measured using Vernier calliper, 100 fruits weight (gm) was measured by using digital balance and oil was extracted from the dried seed kernels $(50 \mathrm{~g})$ by Soxhlet apparatus using petroleum ether $\left(40^{\circ} \mathrm{C}-60^{\circ} \mathrm{C}\right)$ as solvent system. The oil content (\%) was recorded on the dried kernel weight basis as -

Percentage of oil content $=\frac{W_{2}-W_{1}}{50} \times 100$

50

$W_{1}(g)$ - Weight of the empty flask

$\mathrm{W}_{2}(\mathrm{~g})$ - Weight of flask with oil

The progeny testing was carried out in the nursery of College of Forestry, OUAT at Bhubaneswar having average high temperature $\left(32.6^{\circ} \mathrm{C}\right)$, average low temperature $\left(22.4^{\circ} \mathrm{C}\right)$, annual rainfall $(1492 \mathrm{~mm})$ and average relative humidity $(70 \%)$. For progeny testing from each CPT randomly 3 samples with 100 fresh and fully matured fruits per sample were collected. The fruits were kept in water for 24 hours, and then seeds were extracted. Seeds were treated with Diathane M-45 $(3 \mathrm{~g} / \mathrm{kg}$ of seed) and then sown in polypots filled with nursery mixture prepared with soil, sand and FYM mixture of ratio 2:1:1. The number of seed germinated daily up to 30 days after sowing, Seedling length $(\mathrm{cm})$, Fresh seedling biomass $(\mathrm{g})$, Oven dry

Table 1. Provenance details of Terminalia bellirica in Odisha with their climatic and edaphic conditions.

\begin{tabular}{|c|c|c|c|c|c|c|c|c|c|c|}
\hline Provenance & Block & $\begin{array}{l}\text { District of } \\
\text { Odisha }\end{array}$ & $\begin{array}{l}\text { Altitude } \\
\text { (mt.) }\end{array}$ & $\begin{array}{l}\text { Annual } \\
\text { Rainfall } \\
(\mathrm{mm})\end{array}$ & $\begin{array}{l}\text { Avg. Temp. } \\
\left({ }^{\circ} \mathrm{C}\right) \\
\text { (Max. -Min.) }\end{array}$ & $\mathrm{pH}$ & $\mathbf{N}$ & $\mathbf{P}$ & $\mathrm{K}$ & OC \\
\hline Deogan & Deogan & Bolangir & 383 & 1229.47 & $44-8$ & 4.5 & $\mathrm{M}$ & $M$ & $\mathrm{M}$ & $\mathrm{M}$ \\
\hline Bolangir & Bolangir & Bolangir & 383 & 1229.47 & $44-8$ & 4.3 & $M$ & M & $M$ & M \\
\hline Kasturi Bahal & Kishorenagar & Angul & 197 & 1421 & $45-10$ & 6.7 & L & $M$ & L & $\mathrm{L}$ \\
\hline Natada & Talcher & Angul & 875 & 1421 & $47-10$ & 6.0 & L & M & L & L \\
\hline Kantamal & Kantamal & Boudh & 144 & 1510 & $44-10$ & 5.5 & L & M & L & L \\
\hline Jeypore & Jeypore & Koraput & 870 & 1604 & $38-5$ & 4.7 & M & M & L & M \\
\hline Gunupur & Gunupur & Rayagada & 207 & 1340 & $40-5$ & 5.2 & $\mathrm{M}$ & $M$ & M & $M$ \\
\hline Kuchinda & Kuchinda & Sambalpur & 135 & 1638 & $47-11.8$ & 5.5 & $\mathrm{M}$ & $M$ & $M$ & $M$ \\
\hline Ghatikia & Bhubaneswar & Khurda & 45 & 1505 & $45.2-8.2$ & 5.3 & L & L & L & L \\
\hline \multicolumn{11}{|c|}{ * Rating chart of soil characteristics } \\
\hline \multicolumn{2}{|c|}{ Nutrient } & \multicolumn{2}{|l|}{ Low (L) } & \multicolumn{2}{|c|}{ Medium (M) } & \multicolumn{5}{|c|}{ High $(\mathbf{H})$} \\
\hline \multicolumn{2}{|c|}{$\begin{array}{l}\text { Organic carbon }(O C) \\
\text { Available nitrogen }(N) \\
\text { Available Phosphorus }(P)\end{array}$} & \multicolumn{2}{|l|}{$\begin{array}{l}<0.5 \% \\
<240 \mathrm{Kg} / \mathrm{ha} \\
<11.0 \mathrm{Kg} / \mathrm{ha}\end{array}$} & \multicolumn{2}{|c|}{$\begin{array}{l}0.5-7.5 \% \\
240-480 \mathrm{~kg} / \mathrm{ha} \\
11-22 \mathrm{Kg} / \mathrm{ha}\end{array}$} & \multicolumn{3}{|c|}{$\begin{array}{l}>0.75 \% \\
>480 \mathrm{Kg} / \mathrm{ha} \\
>22 \mathrm{Kg} / \mathrm{ha}\end{array}$} & & \\
\hline \multicolumn{2}{|c|}{ Available potassium ( K) } & $<110 \mathrm{Kg} / \mathrm{ha}$ & & \multicolumn{2}{|c|}{$110-280 \mathrm{Kg} / \mathrm{ha}$} & \multicolumn{3}{|c|}{$>280 \mathrm{Kg} / \mathrm{ha}$} & & \\
\hline
\end{tabular}


seedling Biomass $(\mathrm{g})$ were recorded after 90 days of sowing. Basing on the number of seeds germinated, Germination percentage (\%), Mean daily germination (MDG), Peak value (P.V.), Germination Value (G.V.) were calculated as per (Czabator, 1962). The germination index (G.I.) was calculated as described in the Association of Official Seed Analysts (AOSA, 1983). Seedling vigour index was calculated by multiplying seedling length (root length + shoot length) with the corresponding germination percentage and the values were recorded and Seedling Moisture Content (\%) basing on oven dry weight was calculated by the formula

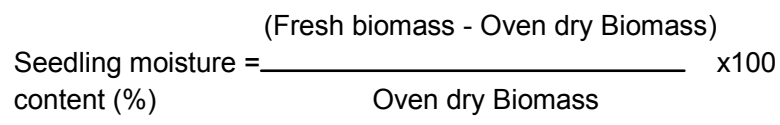

....Eq. 2

The recorded observations were subjected to analysis of variance (ANOVA) as described by Snedecor and Cochran (1967) to understand the significance of differences among provenances. Coefficient of variance $(\mathrm{CV} \%)$ and linear correlation coefficients among studied traits were also calculated. Various genetic parameters like Genotypic Coefficient of Variance (GCV), Phenotypic Coefficient of Variance (PCV), Broad Sense Heritability and Genetic gain were also determined by using the software "Agrigene".

\section{RESULTS}

The present study indicated that the fruit length $(2.21 \mathrm{~cm}-3.87 \mathrm{~cm})$, fruit width $(2.23 \mathrm{~cm}-3.12 \mathrm{~cm}), 100$ fruit weight of fruits $(517.50 \mathrm{gm}-1340.17 \mathrm{gm}), 100$ seed weight $(178.53 \mathrm{gm}-469.05 \mathrm{gm}), 100$ kernel weight (38.38gm - 99.43gm) and the oil content $(27.42 \%$ $41.53 \%)$ of seeds of Terminalia bellirica .varied within provenances. Maximum fruits length $(3.87 \mathrm{~cm})$ and 100 fruit weight $(1340.17 \mathrm{gm}), 100$ seed weight $(649.05 \mathrm{gm})$ and 100 kernel weight(99.43gm) were observed in case of seeds from Kantamal, Maximum fruits width
$(3.12 \mathrm{~cm})$ in Deogan and oil content by kernel wt. basis $(41.53 \%)$ was observed in case of seeds from Kasturi Bahal. However, fruits from Kantamal $(3.09 \mathrm{~cm})$ showed at par with the maximum value in seed width and Deogan (41.14\%) showed at par with maximum oil content (Table 2). The magnitude of variation (Table 3) observed in different seed characters was found higher in 100 seed weight (61.93\%) followed by 100 kernel weight $(61.39 \%)$.

The study showed the extent of variability present in the seedling characters (Table-4). The analysis of variance showed that there was significant variation $(p<0.05)$ in all the seedling characters among other Candidate Plus Trees. The maximum range of variation was observed in case of vigour index of the nursery sown seedling (2047.98-4313.03) followed by seedling moisture content (175.35-228.63); however, the minimum range of variation (1.15-2.01) was observed in case of germination index (Table 5).

The magnitude of variation observed in different seedling characters were found higher in Germination value $(66.84 \%)$ followed by Vigour index $(52.51 \%)$, Peak value $(47.70 \%)$,Fresh biomass $(45.12 \%)$, Germination Index (42.78\%), Mean daily Germination (36.47\%), Germination percent(36.26\%), Nursery seedling length $(30.95 \%)$ and seedling moisture content $(23.30 \%)$ (Table-5).The extent of variability was also accessed by genotypic and phenotypic variances and genotypic and phenotypic coefficient of variation. Most of the seedling traits germination percentage mean daily germination, peak value, germination value, seedling length, vigour index, fresh biomass and seedling moisture content showed higher values of phenotypic variation and phenotypic coefficient of variation than Genotypic variation and Genotypic coefficient of variation. Higher phenotypic coefficient of variation was recorded in germination value (PCV-36.07\%) followed by vigour index (PCV-25.89\%), and the lowest was found in moisture content (PCV-5.63\%) (Table-6). The heritability was found very high for all the seedling traits. Maxi-

Table 2. Variation for seed characters in various provenances of $T$. bellirica.

\begin{tabular}{lllllll}
\hline Provenances & $\begin{array}{l}\text { Fruit length } \\
(\mathbf{c m})\end{array}$ & $\begin{array}{l}\text { Fruit width } \\
\text { (cm) }\end{array}$ & $\begin{array}{l}\text { 100 Fruit } \\
\text { weight } \mathbf{( g m})\end{array}$ & $\begin{array}{l}\text { 100 Seed } \\
\text { weight }(\mathbf{g m})\end{array}$ & $\begin{array}{l}\text { 100 Kernel } \\
\text { weight (gm) }\end{array}$ & $\begin{array}{l}\text { Oil content } \\
\text { (\%) }\end{array}$ \\
\hline Deogan & 3.70 & 3.12 & 903.13 & 325.12 & 71.52 & 41.14 \\
Bolangir & 3.82 & 2.96 & 936.24 & 327.68 & 68.81 & 36.37 \\
Kasturi Bahal & 2.83 & 2.24 & 517.50 & 178.53 & 38.38 & 41.53 \\
Natada & 2.21 & 2.30 & 542.07 & 195.4 & 43.18 & 39.56 \\
Kantamal & 3.87 & 3.09 & 1340.17 & 469.05 & 99.43 & 35.82 \\
Jeypore & 2.88 & 2.23 & 560.78 & 201.88 & 44.41 & 27.42 \\
Gunupur & 2.38 & 2.28 & 551.12 & 187.34 & 41.21 & 32.09 \\
Kuchinda & 2.24 & 2.24 & 597.17 & 209.23 & 45.40 & 33.67 \\
\hline
\end{tabular}


Das, H. et al. / J. Appl. \& Nat. Sci. 12(3): 319 - 327 (2020)

Table 3. Analysis of variance and magnitude of variation of seed characters of $T$. bellirica.

\begin{tabular}{lcccccc}
\hline Seed Characters & F-Value & Mean & Range & SED & CD (5\%) & $\begin{array}{c}\text { Magnitude of } \\
\text { Variation (\%) }\end{array}$ \\
\hline Fruit Length & 709.016 & 3.02 & $2.21-3.87$ & 0.036 & 0.067 & 42.89 \\
Fruit Width & 548.133 & 2.61 & $2.23-3.120$ & 0.025 & 0.054 & 28.52 \\
Fruit weight & 153.255 & 731.42 & $517.5-1340.17$ & 15.809 & 33.515 & 61.38 \\
100 Seed weight & 137.22 & 257.22 & $178.53-469.05$ & 4.83 & 9.81 & 61.93 \\
100 Kernel weight & 143.76 & 55.88 & $38.38-99.43$ & 1.02 & 2.23 & 61.39 \\
Oil content & 0.832 & 36.13 & $27.42-41.53$ & 0.438 & 0.928 & 33.97
\end{tabular}

mum heritability was observed in germination (99.9\%), Seedling length (99.9\%), Vigour index (99.9\%), Oven dry biomass $(99.9 \%)$ and Seedling moisture content $(99.9 \%)(T a b l e-6)$. The genetic gain was found higher in seedling traits like Germination value, Vigour index, Peak value, Oven dry biomass and Fresh biomass. The lower genetic gain was recorded in other seedling traits like moisture content. The genetic gain was found highest in germination value $(71.97 \%)$ followed by Vigour index $(53.30 \%)$, and the lowest was found in moisture content (15.44\%) (Table-6).

Correlation between most of the morphological traits of seed and germination and morphological traits of seedling of progeny test was found positive. Oil content did not show significant correlation with any of the seed, germination and seedling morphological characters. Fruit weight showed positive correlation in case of seed characters with seed weight $(0.94)$, Kernel weight $(0.81)$, Fruit length $(0.80)$ and Fruit width $(0.76)$ and germination characters like germination percentage $(0.907)$, mean daily germination (0.899), peak value $(0.781)$, germination value $(0.8910$, germination index $(0.872)$,seedling length (0.596), vigour index $(0.884)$ and seedling dry weight $(0.765)$ except seedling moisture content . Similarly, Seed weight showed positive correlation with kernel weight (0.895), germination characters with like germination percentage (0.934), mean daily germination (0.911), peak value $(0.812)$, germination value $(0.923)$, germination index (0.895) and seedling characters with seedling length (0.531), vigour index (0.942) and seedling dry weight (0.653) (Table 7).

\section{DISCUSSION}

Variation refers to the observable difference in individuals for a particular seed character. In the present investigation mean fruit length was found $(3.02 \pm 0.03 \mathrm{~cm})$, fruit width $(2.61 \pm 0.02 \mathrm{~cm}), 100$ fruit weight $(731.42 \pm 15.80 \mathrm{gm}), \quad 100$ seed weight $(257.84 \pm 4.83 \mathrm{gm}), 100$ kernel weight $(55.88 \pm 2.23 \mathrm{gm})$ and oil content $(36.13 \pm 0.43 \%)$ in all seeds with signifi- cant difference $(p<0.05)$. Besides, the ranges of variations of each fruit character in all the 9 provenances also revealed significant differences (Table 3 ). These variations may be due to the fact that this species grows over a wide range of climate as well as edaphic conditions in different provenances (Table 1). Though very little information is available on seed variability study from different provenances in T. bellirica. Similar type of studies on seed morphological variation from different provenances were reported by Nayak et al. (2020) in Mahuca latifolia of Odisha,Abraham et al. (2010) in case of M. longifolia of Tamil Nadu and Podducherry, Police et al. (2013) and Vasanth Reddy et al. (2007) in Pongamia pinnata of Karnataka and Gairola et al. (2011in Jatropha curcas of Uttrakhand. The magnitude of variation ranged from high to moderate in all seed traits with a maximum in seed weight $(61.93 \%)$ followed by kernel weight $(61.39 \%)$, fruit weight $(61.38 \%)$, fruit length $(42.89 \%)$, oil content in the kernel $(33.97 \%)$ and seed width $(28.52 \%)$ (Table 3 ). This indicated that variations in seed characteristics of $T$. bellirica (Gaertn.) Roxb. occurred in this distribution range and the higher value characters may be taken up for the improvement of the species. Variability in seed traits and oil content of 24 accessions of $J$. curcas collected from different agroclimatic zones of Haryana were assessed by Kaushik et al. (2007) and significant differences $(P<0.05)$ in seed size, 100 -seed weight and oil content between accessions were reported. Similarly, Gingwal et al. (2005) also reported that variability also exists in $J$. curcas with respect to seed morphology.

The maximum Germination percentage $(73.32 \%)$ was recorded in Kantamal provenance (Table 4) which may be due to its maximum seed weight and the environmental condition of nursey under which seedling is raised. This is in line with the study made by Dwivedi (1993) in Azadirachta indica and Devagiri et al. (1998) in Dalbergia sissoo. They found that the variation observed in the seed characters may be attributed to adverse environmental and differences in their distri- 
Das, H. et al. / J. Appl. \& Nat. Sci. 12(3): 319 - 327 (2020)

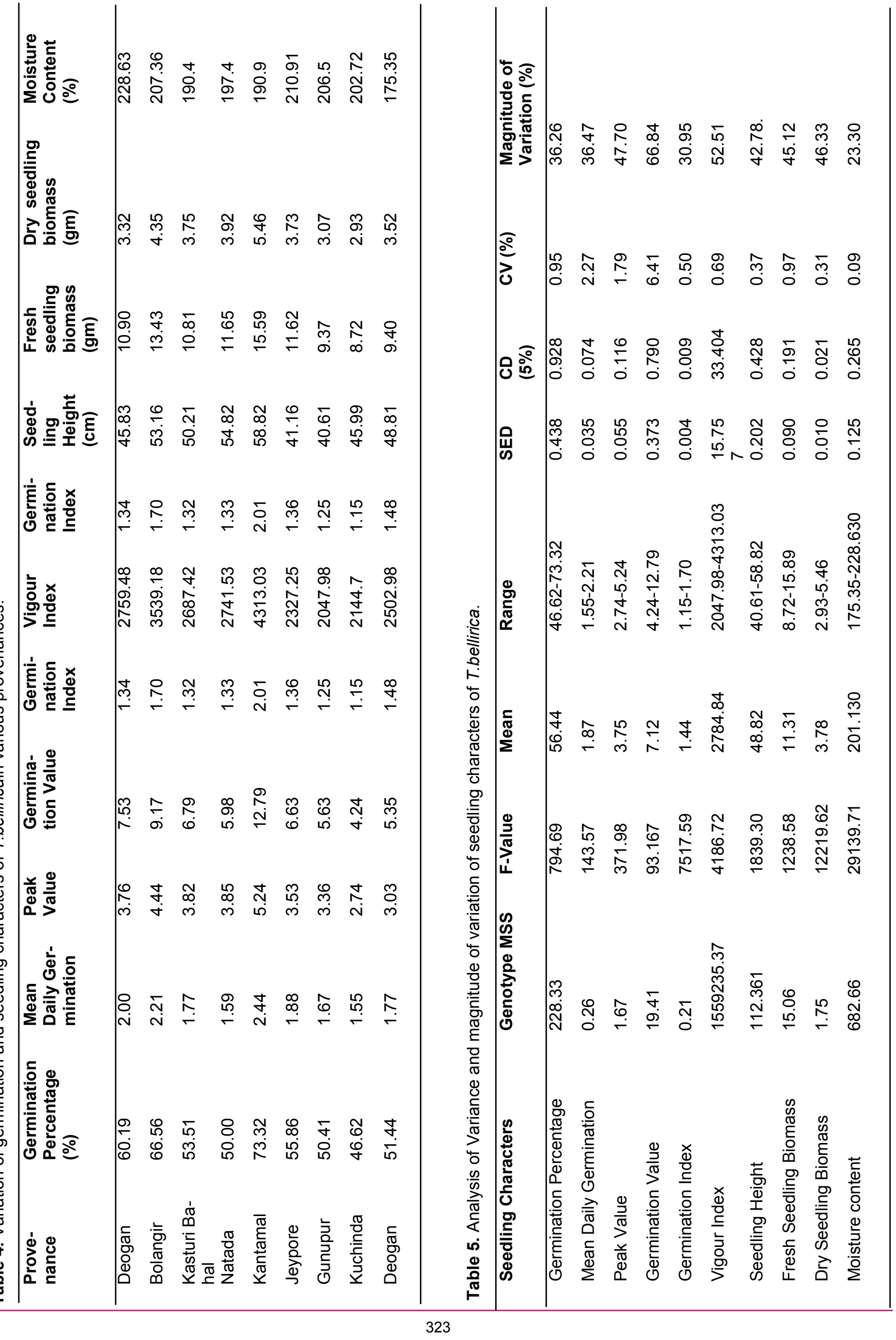


bution range. This, in turn, affects the germination of seeds. Weis (1982) reported that larger sized seeds frequently have greater germination percentage than smaller sized seeds. In the present study, the maximum value of Mean daily germination (2.44) was also observed in Kantamal provenance as germination percentage in Kantamal provenance was highest and days taken for the standard germination test was 30 days for all germplasms. The maximum Peak value (5.24) was recorded in the Kantamal provenance as the number of days required to achieve the peak germination was less although the germination percentage remained nearly the same as Kantamal provenance. Similarly, the maximum Germination value (12.79) was also found in Kantamal provenance, which may be due to high peak value and mean daily germination. Germination index was also recorded maximum (2.01) in Kantamal provenance which may be due to genetical makeup of the seed source and its interaction with microenvironmental factors within nurseries like soil temperature, atmospheric temperature, relative humidity and water holding capacity of nursery soil mixture which affects the daily rate of germination. Maximum seedling height $(58.83 \mathrm{~cm})$ was observed in Kantamal provenance which may be due to maximum seed weight of Kantamal provenance that provides more food production of healthy seedling in the earlier stages promoting better seedlings (5.46gm). The maximum Vigour index (4313.03) was found in Kantamal provenance, which may be due to high values of germination percentage and seedling length. The maximum Fresh weight of seedlings $(15.89 \mathrm{gm})$ and oven-dry weight $(5.46 \mathrm{gm})$ was record- ed in Kantamal provenance (Table-4) which may be because of better growth of seedlings. The finding was also inline as reported by Saverimuttu and Westoby (1996) that the seedling from a larger sized seed may have sufficient reserves to continue growth for a much longer period. Zimmerman and Weis (1983) also reported that seed size affects seedling biomass. In the present investigation, observable differences within seedling characters were observed for all seedling characters recorded the mean value of Germination percentage was found $(56.44 \pm 0.43)$, mean daily germination (1.87 \pm 0.03$)$, Peak value $(3.75 \pm 0.05)$, germination value $(7.12 \pm 0.37)$, germination index (1.150 \pm 0.004$)$, seedling height $(48.82 \pm 0.20)$, vigour index (2784.84 \pm 15.75$)$, fresh seedling biomass (11.31 \pm 0.09$)$, oven-dry seedling biomass $(3.78 \pm 0.01)$ and seedling moisture content $(201.13 \pm 0.12)$ in all seeds with a significant difference. Besides that, the ranges of variation and the magnitude of variation of each germination and seedling character in all the 9 provenances also revealed significant differences (Table 5) which indicate that variations in germination and seedling characters occurs and has good scope for improvement. The extent of variability is also assessed by genotypic and phenotypic variances and genotypic and phenotypic coefficient of variation (Subramaniam et al., 1995). All the germination parameters i.e. germination percentage, mean daily germination, peak value, germination value, germination index, vigour index and morphological and biomass parameters studied like seedling height, fresh biomass of seedling, oven-dry biomass of seedling and moisture content of seedling of variation showed high-

Table 6. Phenotypic and Genotypic analysis of seedling characters of T. bellirica (Gaertn.) Roxb.

\begin{tabular}{|c|c|c|c|c|c|c|c|c|}
\hline $\begin{array}{l}\text { Seedling } \\
\text { Characters }\end{array}$ & GV & PV & EV & $\begin{array}{l}\text { GCV } \\
(\%)\end{array}$ & $\begin{array}{l}\text { PCV } \\
(\%)\end{array}$ & $\begin{array}{l}\text { ECV } \\
(\%)\end{array}$ & $\begin{array}{l}\text { Heritability } \\
(\%)\end{array}$ & $\begin{array}{l}\text { Genetic } \\
\text { gain (\%) }\end{array}$ \\
\hline $\begin{array}{l}\text { Germination } \\
\text { Percentage }\end{array}$ & 76.01 & 76.30 & 0.287 & 15.44 & 15.47 & 0.94 & 99.6 & 31.75 \\
\hline $\begin{array}{l}\text { Mean Daily } \\
\text { Germination }\end{array}$ & 0.08 & 0.08 & 0.002 & 15.66 & 15.83 & 2.27 & 97.9 & 31.93 \\
\hline Peak Value & 0.55 & 0.56 & 0.005 & 19.86 & 19.94 & 1.78 & 99.2 & 40.75 \\
\hline $\begin{array}{l}\text { Germination } \\
\text { Value }\end{array}$ & 6.40 & 6.61 & 7.208 & 35.50 & 36.07 & 6.40 & 96.8 & 71.97 \\
\hline $\begin{array}{l}\text { Germination } \\
\text { Index }\end{array}$ & 0.06 & 0.07 & 0.01 & 18.36 & 18.36 & 0.36 & 99.9 & 37.82 \\
\hline Vigour Index & 519620.96 & 519993.40 & 372.424 & 25.88 & 25.89 & 0.69 & 99.9 & 53.30 \\
\hline Seedling Height & 37.43 & 37.49 & 0.061 & 12.53 & 12.54 & 0.50 & 99.8 & 25.79 \\
\hline Fresh Biomass & 5.01 & 5.03 & 0.012 & 19.79 & 19.82 & 0.97 & 99.7 & 40.73 \\
\hline $\begin{array}{l}\text { Oven Dry } \\
\text { Biomass }\end{array}$ & 0.62 & 0.58 & 0.02 & 20.18 & 20.19 & 0.31 & 99.9 & 41.58 \\
\hline $\begin{array}{l}\text { Moisture } \\
\text { Content }\end{array}$ & 227.54 & 227.57 & 0.023 & 7.50 & 7.50 & 0.07 & 99.9 & 15.44 \\
\hline
\end{tabular}




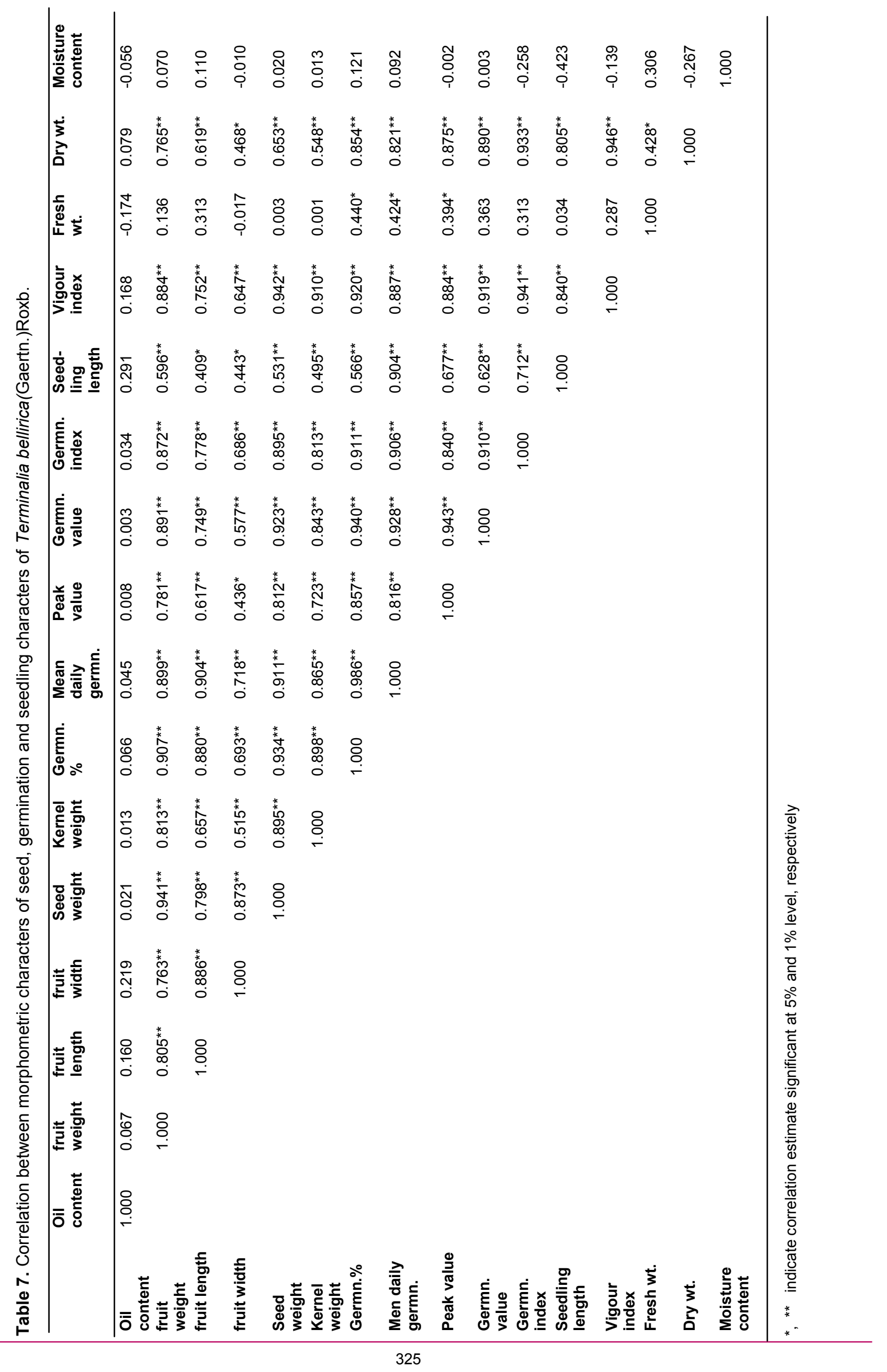


er value for the phenotypic coefficient of variation (Table 6). This indicated that all these traits are greatly influenced by the environment. Higher values for the phenotypic coefficient of variation as compared to genotypic coefficient of variation in germination and nursery growth parameters were also observed by Wani and Wani (2013) during genetic variability study of germination and seedling traits of Madhuca indica .

The proportion of total variation, which is heritable, is termed as heritability in a broad sense (Lush, 1937). Knowledge of heritability magnitude gives us an idea about the scope of effecting genetic improvement through selection. Johnson et al. (1995) observed that high genetic gain is usually more useful than the heritability value alone in predicting the resultant effect from selecting the best individual/seed source and therefore, a heritability estimate alone does not necessarily mean an increased genetic advance. Vigour index, Oven-dry biomass, peak value and Germination value were found very high heritability and genetic gain indicating a wide scope of genetic improvement (Table-6). Similarly, seeds collected from Candidate plus tree have been evaluated for various seed germination and seedling traits following progeny testing in $M$. indica at Uttar Pradesh by Wani and Ahmad (2013), Wani and Wani (2013) and reported to have high heritability and expected genetic gain in germination and nursery growth parameters. Ramachandra (1996) in Acacia catechu at Uttarakhand, Devagiri et al. (1997) in Heracleum candicans at Himachal Pradesh, Srivastava et al. (1993) in Terminalia arjuna in Jharkhand, Sharma and Sharma (1995) in Grewia optiva at Himachal Pradesh and Subramanium et al. (1995) in Eucalyptus grandis at Tamil Nadu also carried out similar works. On the basis of germination and seedling growth characters, Kantamal provenance can be considered better and may be recommended for further genetic improvement program (Table-4). Kantamal also showed the highest fruit weight seed weight, kernel weight among other seeds collected from various provenances. Although oil content in case of Kantamal was $35.82 \%$ which was $15.94 \%$ less oil content than the oil content of Kasturi Bahal, however, the oil yield was more in Kantamal provenance as the kernel weight was $159.06 \%$ more than Kasturi Bahal(Table-2). However, the seedling seed orchard grown from these raised seedlings of different provenances may be studied in future to confirm the best genotype in terms of oil yield and further improvement programme.

\section{Conclusion}

The present study concluded that significant variations occur among the different provenances of Odisha state in oil content, seed morphological, germination and seedling characters of $T$. bellirica which can be taken up for further improvement work on the species. Kantamal provenance under Boudh district of Odisha showed higher oil yield among all the provenances which can be presently recommended for collection of seed for oil purpose to meet the biodiesel and other industrial uses.

\section{REFERENCES}

1. Abraham, Z. Yadav, S. Latha, M. Mani, S. Mishra, and S. K. (2010). Seed variability in Madhuca longifolia (Koenig) J. F. Macbride, a source of oil for use as bio-energy. Genet Resour Crop E. 57:619-623.

2. Ahn,M.H,Kim,C.Y,Lee,J,S,Kim,T.G.,Kim,S.H,Lee,C.K,Lee, B.B,Shin,G.G,Huh,H.,Kim, J. (2002).Inhibition of HIV-I integrase by galloyl glucose from Terminalia chebula and flavonol glycoside gallates from Euphorbia pekinensis. Planta Med.68:457-459.

3. AOSA (1983). Association of Official Seed Analysis, 1983, "Seed Vigor Testing Handbook. Contribution," 1983. No.32 to the handbook on Seed Testing, published by AOSAand SCST, USA.

4. Chatterjee, S. and Pakrasi, S.C. (2000). The Treaties on Indian Medicinal Plants, National Institute of Science Communication and InformationResources, 3:203-204.

5. Chhetri A.B., Tango M.S., Budge S.M., (2008) Non-edible plant oils as new sources for biodiesel production. International Journal of Molecular Sciences, 9 (2): 169-180.

6. Czabator, F.J. (1962) Germination value: an index combining speed and completeness of Pine seed germination. Forest Science 8: 386-396.

7. Deb A., Barua, S. and Das, B. (2016). Pharmacological activities of Baheda (Terminalia bellerica): A review. Journal of Pharmacognosy and Phytochemistry, 5(1): 194-197.

8. Demirbas, A., Bafail, A., Ahmad, W. and Manzoor Sheikh, W. (2016). Biodiesel production from non-edible plant oils. Energy Exploration \& Exploitation, 34(2) 290318.

9. Devagiri, G. M., Dhiman, R .C, Thapiyal, R. C. and Nautiyal, S. (1998). Seed source variation in pod and seed traits of Dalbergia sissoo.Ann. For., 6: $148-155$.

10.Dwivedi, A. P.1993, National level of Neem Seed source trials at Jodhpur. Syst. Ecol. Contrib. 5(7):20-34.

11.Gairola, K.C. Nautiyal, A.R. Sharma, G. and Dwivedi, A.K. (2011).Variability in Seed Characteristics of Jatropha curcas Linn. From Hill Region of Uttarakhand. Bulletin of Environment, Pharmacology \& Life Sciences1(1):64-69.

12.Ginwal, H. S., S. S. Phartyal, P. S. Rawat and R. L. Srivastava (2005). Seed source variation in morphology, germination and seedling growth of Jatropha curcas Linn.in Central India. Silvae Genetica 54:76-80.

13.Gupta, G. Handa, A.K. Ajit and Maurya, D. (2016). Variation in seed and seedling traits of Pongamia pinnata. Indian Forester 142 (9) : 852-857.

14.Johnson, H.W., Robinson, H.F. and Comstock, R.E. (1955). Genotypic and phenotypic correlations in soybean and their implications in selections. Agron J, 47: 477-483.

15.Kaushik, N., K. Kumar, S. Kumar and S. Roy (2007). Genetic variability and divergence studies in seed traits and oil content of Jatropha (Jatropha curcas L.) accessions. 
Biomass and Bioenergy 31:497-502.

16.Kaushik, N., K. Kumar, S. Kumar and S. Roy., R.S. Beniwal, N.Kousik and S.Ray (2007). Genetic variability and association studies in pot and seed traits of Pongamia pinnata (L.) Pierre in Haryana, India, Genetic resources and crop evaluation,54(8):1827-1832.

17.Lush, J.C.(1937). Animal Breeding Plans. State College Press, Ames, Lowa.

18.Marwaha, A., Rosha, P., Mohapatra, S.K. Mahla, S.K. and Dhir, A. (2019). Biodiesel production from Terminalia bellerica using eggshell-based green catalyst: An optimization study with response surface methodology.Energy Reports, 5: 1580-1588.

19.Nayak, S., Sahoo, U.K., Thangjam, U. and Garnayak L.M. (2020). Provenance variations of morphometric traits and oil contents of Madhuca latifolia Macbride in Odisha: Implication for tree improvement. Journal of Experimental Biology and Agricultural Sciences, 8(3): $224-232$

20.Pavithra, H. R., Gowda, B., Prasanna, K.T. and Shivanna, M.B.(2013). Pod and Seed Traits in Candidate Plus Trees of Pongamia pinnata (L.) Pierre from Southern Peninsular India in Relation to Provenance Variation and Genetic Variability, J. Crop Sci. Biotech.16 (2): 131-142.

21.Police Patil, V. M., Shivanna, H., Surendra, P., Manjunath, G.O., Krishna, A. and Dasar, G. V. (2011). Variability studies for seed and seedling traits in Pongamia pinnata (L.)Pierre. Karnataka J. Agric. Sci., 24 (2): 201-203.

22.Ramachandra, N.G. (1996). Provenance variation in seed and seedling parameters in Acacia catechu. Wild. PhD Thesis, FRI Deemed University, Dehradun

23._Rudreshaiah,O.B., Venkatesh, Y.K. and Ramappa, S. ( 2019). Terminalia bellirica: a new biodiesel for diesel engine: a comparative experimental investigation. Environmental Science and Pollution Research, 27: 1443214440.

24.Salami, K. D. and Akinyele, A.O. (2015). Provenance variation in seed and seedlings attributes of Jatropha curcas Linn. in South-Western Nigeria. Direct Research Journal of Agriculture and Food Science, 3 (7): 143-147.

25.Saverimuttu,T and Westoby, M. (1996).Seedling longevity under deep shade in relation size. Journal Ecology, 84:681-689.
26.Sharma, S.S., Islam, M.A., Malik, A.A., Kumar, K., Negi, M.S. and Tripathi S. B. (2016). Seed traits, fatty acid profile and genetic diversity assessment in Pongamia pinnata (L.) Pierre germplasm. Physiol Mol Biol Plants, 22(2):193205.

27.Sarin R., Sharma M. and Khan A. A. (2010). Terminalia belerica Roxb. seed oil: A potential biodiesel resource. Bioresource Technology, 101(4): 1380-138

28.Saverimuttu, T and Westboy, M. (1996).Seedling longevity under deep shade in relation to size. J.Ecol.,84:681689.

29.Sharma, R.K. and Sharma, S.S. (1995). Heritability and association analysis in Grewiaoptiva. Indian Forester, 121 (4):318-320

30.Snedecor, G.W. and Cochran, W.G. (1967). Book Review Statistical Methods G.Sixth edition. Ames, lowa: lowa State University Press, Book Review Statistical Methods 8:593.

31. Srivastava, D.P., Srivastava, P.K., Goel, A.K. and Thangavelu,, K. (1993). Genetic variability in Terminalia arjuna Bedd. Ind. J.For. 16(3):223-225

32.Subramanian, K. N., Mandal, A.K. and Nicodemus, A. (1995). Genetic variability and characters association in Eucalypyus grandis. Ann. For., 3(2):134-137

33.Vasanth Reddy, K.N., Pradeep Kumar, H., Siddraju, C.M., Rajesh P. Gunga, Madiwalar, S.L. and Patil, S.K. (2007). Seed source variation for seed and seedling traits in Pongamia pinnata (L.) Pierre; An important biofuel yielding tree species. My For., 43 (1):61-68

34.Wani, M.S. and Ahmad, L. (2013). Estimation of field environment variability for germination and seedling traits in Madhuca indica Gmel. American Journal of Experimental Agriculture. 3 (2):361-373.

35.Wani, M.S. and Wani, A.M. (2013). Genetic variability and association analysis in Madhuca indica Gmel. Indian Forester, 139 (8):692-698

36.Weis.M.L. (1982).The effect of propagule size on germination and seedling growth in Mirbilis histue. Can. J. Bot., 60:1868-1874.

37.Zimmerman.J.K and Weis, M.L.(1983).Fruit size variation and effects on germination seedling growth in Xanthium strumarium. Can.J.Botan., 61: 2309-2315. 